\section{EOMF Celebrates 10 Year Mile- stone in its Forest Certification Program}

On the evening of March 21 ${ }^{\text {st }}$, the Eastern Ontario Model Forest (EOMF) was pleased to welcome nearly 100 guests at Strathmere Lodge in North Gower to celebrate a milestone achievement for its Forest Certification Program. In addition to accolades acknowledging the $10^{\text {th }}$ Anniversary of this successful Program, the Rainforest Alliance presented Scott Davis, the EOMF's Forest Certification Coordinator, with its third Five Year Forest Stewardship Council ${ }^{\circ}$ $\left(\mathrm{FSC}^{\circ}\right)$ Certificate along with a 10 Year commemorative plaque.

"The Forest Stewardship Council has developed a set of internationallyrecognized principles for sustainable forest management practices that are used throughout the world. Canada can boast the highest percentage of FSCcertified forest globally", said Davis. "The EOMF contributed significantly to making Ontario a leader in Canada, and has demonstrated a commitment to the forest certification process".

The Rainforest Alliance is an FSCaccredited third-party certification body that interacts and audits at the ground-level with individuals and organizations seeking, or having achieved, FSC certification. "The EOMF pioneered the establishment of a Group FSC Certificate (FSC ${ }^{\oplus}$ C018800) that has enabled a multitude of private landowners and community forests to certify their woodlots with greater ease and affordability. They did this by assuming the roles and responsibilities of managing the Certificate to established standards and coordinating efforts with us as we too evolved over the past 10 years", remarked Richard Donovan, Vice President of Forestry for the Rainforest Alliance. "Their Program has served as a model for others, meaning the EOMF's reach and impact now extends far beyond Eastern Ontario".

From humble beginnings, the EOMF Forest Certification Program now includes over 135 forest owners and nine community forests representing over 55000 hectares of FSC-certi-

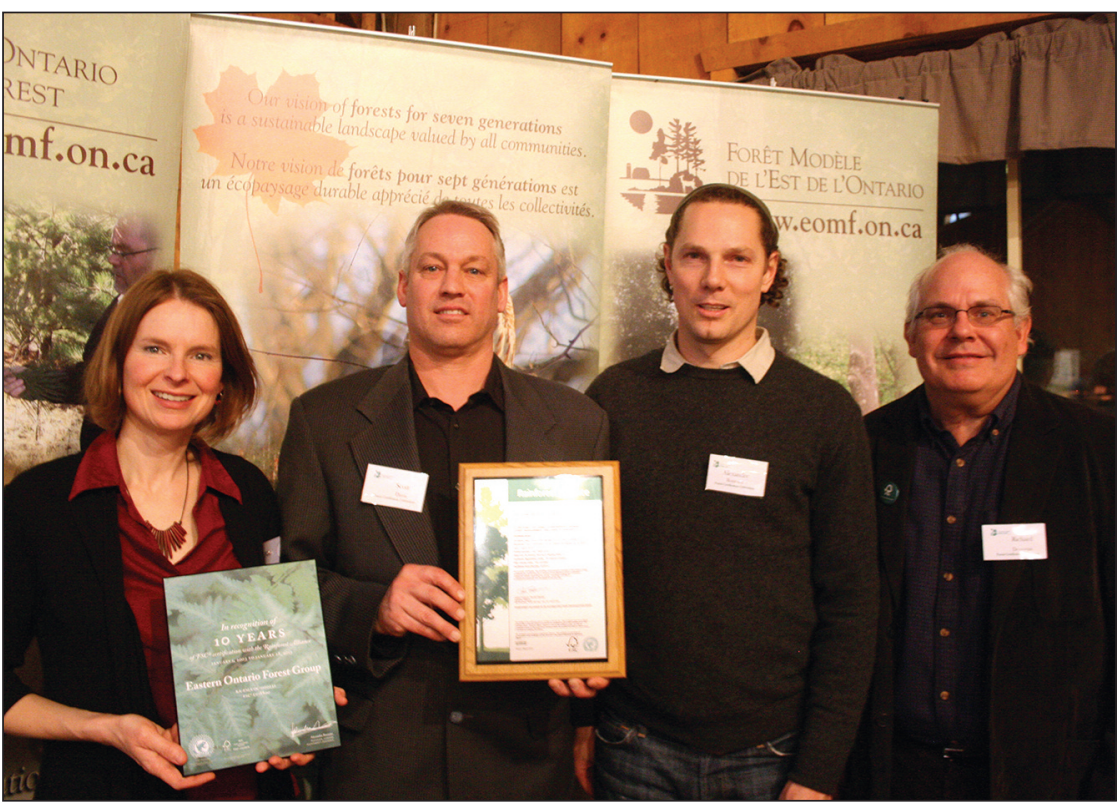

L-R Vivian Peachey FSC Canada; Scott Davis EOMF Forest Certification Coordinator; Alex Boursier Rainforest Alliance Canada; Richard Donovan VP of Forestry Rainforest Alliance.

fied forest throughout southern Ontario. Wade Knight, EOMFs General Manager, gave the audience an informed overview of the 10 years progression of the program.

Another significant achievement of the Program was the creation of FSC maple syrup certified offering. Ray Fortune, EOMF past president and FSC certified maple syrup producer, spoke on the early days of working with the FSC and the Rainforest Alliance to develop the first maple syrup standard. "FSC-certified maple syrup has travelled the world as gifts to foreign dignitaries and others. Bottles of FSClabelled syrup are often one of the gifts of choice given by Canadian politicians and companies to symbolize both the essence and uniqueness of Canada, and its commitment to environmental and socio-economic sustainability."

The EOMF thanks its many partners, supporters and friends that have contributed to its program over the years. Of notable mention are its founding partners, the Ontario Woodlot Association, Domtar Cornwall, and the Ontario Ministry of Natural Resources. The EOMF wishes to acknowledge the support and help it has enjoyed and appreciated along the way from individuals, companies and organizations in the forest industry, at all levels of government, NGOs, First Nations partners, consultants and service providers, staff and others too numerous to mention that have contributed to the program's growth and success.

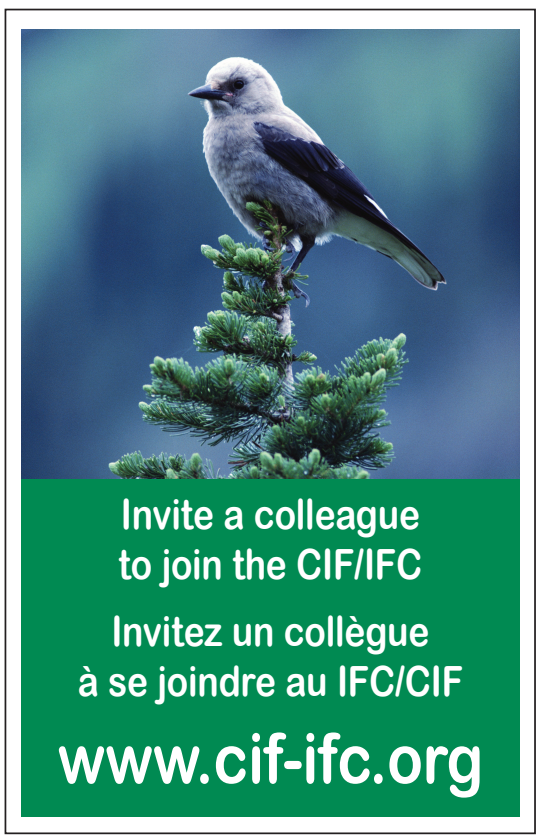

